\title{
MMP-1 expression has an independent prognostic value in breast cancer
}

\author{
Pia Boström", Mirva Söderström ${ }^{1}$, Tero Vahlberg ${ }^{2}$, Karl-Ove Söderström¹, Peter J Roberts ${ }^{3}$, Olli Carpén ${ }^{1}$ and \\ Pirkko Hirsimäki ${ }^{1}$
}

\begin{abstract}
Background: Breast cancer consists of a variety of tumours, which differ by their morphological features, molecular characteristics and outcome. Well-known prognostic factors, e.g. tumour grade and size, Ki-67, hormone receptor status, HER2 expression, lymph node status and patient age have been traditionally related to prognosis. Although the conventional prognostic markers are reliable in general, better markers to predict the outcome of an individual tumour are needed.

Matrix metalloproteinase-1 (MMP-1) expression has been reported to inversely correlate with survival in advanced cancers. In breast cancer MMP-1 is often upregulated, especially in basal-type breast tumours. The purpose of this retrospective study was to analyse MMP-1 expression in breast cancer cells and in cancer associated stromal cells and to correlate the results with traditional prognostic factors including p53 and bcl-2, as well as to patient survival in breast cancer subtypes.
\end{abstract}

Methods: Immunohistochemical analysis of MMP-1, ER, PR, Ki-67, HER2, bcl-2, p53 and CK5/6 expression was performed on 125 breast cancers. Statistical analyses were carried out using Kruskal-Wallis and Mann-Whitney -tests. In pairwise comparison Bonferroni-adjustment was applied. Correlations were calculated using Spearman rank-order correlation coefficients. Kaplan-Meier survival analyses were carried out to compare breast cancer-specific survival curves. Factors significantly associated with disease-specific survival in univariate models were included in multivariate stepwise.

Results: Positive correlations were found between tumour grade and MMP-1 expression in tumour cells and in stromal cells. P53 positivity significantly correlated with MMP-1 expression in tumour cells, whereas HER2 expression correlated with MMP-1 both in tumour cells and stromal cells. MMP-1 expression in stromal cells showed a significant association with luminal A and luminal B, HER2 overexpressing and triple-negative breast cancer subtypes.

Conclusions: The most important finding of this study was the independent prognostic value of MMP-1 as well as Ki-67 and bcl-2 expression in tumour cells. Our study showed also that both tumoural and stromal MMP-1 expression is associated with breast tumour progression and poor prognosis. A significant difference of MMP-1 expression by cancer associated stromal cells in luminal A, luminal B and triple-negative breast cancer classes was also demonstrated.

Please see related commentary article http://www.biomedcentral.com/1741-7015/9/95

\section{Background}

Breast cancer consists of a variety of tumour types, which differ by their morphology, molecular characteristics and clinical outcome. It is the leading cause of cancer death among women aged 20-59 years in high-income countries [1]. The prognostic factors that indicate disease

\footnotetext{
* Correspondence: pia.bostrom@tyks.fi

'University of Turku and Turku University Central Hospital, Department of

Pathology, Kiinamyllynkatu 10, 20520 Turku, Finland

Full list of author information is available at the end of the article
}

outcome include tumour grade and size, proliferation index Ki-67, hormone receptor status, HER2 expression, lymph node status and patient age. In addition, several markers including p53 [2] and bcl-2 [3,4] expression have been shown to associate with survival.

The current breast cancer classification is based on morphological features [5]. Newer approaches to molecular classification by gene expression profiling have identified five distinct subclasses [6,7]. Two of them are ER positive (luminal A and B) and three ER negative

\section{Biomed Central}


(HER2 overexpression, normal breast-like and basal-like types) with different prognoses and treatment responses to current therapies. Basal-like cancers are negative for hormone receptors, but positive for basal cytokeratins. Triple-negative breast cancers lack expression of HER2, estrogen and progesterone receptors. The majority of triple-negative breast cancers carry the basal-like molecular profile [8].

Although well-documented classical prognostic markers are reliable in general, better markers to predict the outcome of an individual tumour are needed. It would be especially important to identify patients with favourable outcome and to save them from treatment side-effects. On the other hand, tumours that have capability to metastasize need targeted treatment and intensified follow-up.

Tumour invasion and metastasis is a multistage process, which includes tumour growth, local proteolysis and migration of the tumour cells through the degraded tissue [9]. All these steps involve interaction between tumour cells and the extracellular matrix (ECM). Local proteolysis is carried out by proteinases produced by the tumour cells or by the surrounding stromal cells. Matrix metalloproteinases (MMPs) are a family of enzymes consisting of 28 members [10] capable of degrading essentially all macromolecules of the ECM [11]. The activity of MMPs is controlled extracellularly by tissue inhibitors of matrix metalloproteinases (TIMPs) [12]. A number of studies have demonstrated a correlation between MMP expression and the invasive potential of human cancer [13]. Furthermore, the ratio of MMPs to TIMPs has been related to the prognosis of several human tumours, including breast cancer [14,15]. Recent studies have also shown that MMPs' functional genetic polymorphisms may contribute to breast cancer risk [16]. In most malignant tumours, stromal fibroblasts have been shown to be the predominant source of MMPs [17], but there is also evidence that MMPs are produced by cancer cells [18].

MMP-1 has been described in a wide range of advanced cancers with a significant negative correlation with survival $[18,19]$. MMP-1 is often upregulated in breast cancer, especially in basal-type tumours [20], and is supposed to be critically involved in metastatic dissemination [21,22]. Recent reports suggest that MMP-1 associates with a shortened relapse free survival [23] and poor outcome in breast cancer [20].

In most previous studies MMP-1 expression has been analyzed at mRNA rather than at protein level. Therefore, the purpose of this retrospective study was to analyse the exact location of MMP-1 expression both in breast cancer cells as well as in cancer associated stromal cells and to correlate the results with traditional prognostics factors and with bcl-2 and p53 expression in different breast cancer subtypes. In addition, we wanted to correlate MMP-1 expression to breast cancerspecific survival during an extensive follow-up time.

\section{Methods}

\section{Patients and tissue material}

The material consisted of 118 female breast cancer patients whose tissue samples were available (mean age at surgery was 57,5 years, range $30-90$ years) and who were operated and treated at Turku University Central Hospital during 1985-1994. In addition, to increase the number of basal-like subtype seven patients operated in 2007 were included in the study. Due to the retrospective nature of the study, informed consents could not be obtained from individual patients. The permission to use the tissue material without informed content was given by the local and national regulatory authorities, Turku University Hospital Ethics committee (no 241/2005) and the Finnish National Authority for Medicolegal Affairs (no 4424/32/300/02). Follow-up information on life status was collected for each case (Central Statistical Office of Finland). Tumour characteristics including tumour size, grade and lymph node status were obtained from the pathology database (Table 1). None of the patients received radiation or chemotherapy before operation. All breast tumours were invasive carcinomas and most of them were symptomatic.

Four $\mu \mathrm{m}$ thick serial sections from formalin-fixed, paraffin-embedded tumour tissue were cut and stained with haematoxylin and eosin. Slides were reviewed to confirm the diagnosis. The tumour histology was assessed according to the WHO classification [5] and tumour grading (I-III) was based on the recommendations made by Elston and Ellis 1991 [24].

\section{Immunohistochemistry}

Immunohistochemical staining of MMP-1, ER, PR, Ki-67, HER2, bcl-2, p53 and CK5/6 was carried out with TechMate 500+ immunostainer using monoclonal antibodies and a peroxidase/diaminobenzidine LSAB+ or EnVision detection kit (DAKO). Immunodetection of MMP-1 was performed using mouse monoclonal MMP-1 antibody (Onkogene) with dilution 1:100 and $10 \mathrm{mM}$ TRIS-HCl with $1 \mathrm{mM}$ EDTA (pH9) as a pretreatment. Immunohistochemical staining of ER, PR, Ki-67, HER2, bcl-2, p53 and CK5/6 were performed as described [25]. The used MMP-1 antibody recognises both the latent and the active forms of MMP-1 protein.

MMP-1 (Figures 1a-e), p53, HER2, ER, PR, Ki-67 and bcl-2 staining was evaluated from cells at the border of the most cellular part of the tumour. Areas showing necrosis or inflammation were excluded from the analysis. For MMP-1 expression the number of immunopositive tumour cells per 100 malignant cells (0-100\%) from 
Table 1 Patients and tumour characteristics

\begin{tabular}{|c|c|}
\hline Variable & Number of patients (\%) \\
\hline Number of the patients & $\begin{array}{l}125 \text { (aged 30-90, mean } \\
57,5)\end{array}$ \\
\hline \multicolumn{2}{|l|}{ Grade } \\
\hline I & $10(8 \%)$ \\
\hline$\|$ & $66(52,8 \%)$ \\
\hline III & $49(39,2 \%)$ \\
\hline \multicolumn{2}{|l|}{ Axillary nodal status } \\
\hline NO & $64(51,2 \%)$ \\
\hline$\geq \mathrm{N} 1$ & $50(40 \%)$ \\
\hline Unknown & $11(8,8 \%)$ \\
\hline \multicolumn{2}{|l|}{ Estrogen receptor status (ER) ${ }^{1)}$} \\
\hline Positive & $80(64 \%)$ \\
\hline Negative & $45(36 \%)$ \\
\hline \multicolumn{2}{|l|}{ Progesterone receptor status (PR) $)^{1)}$} \\
\hline Positive & $82(65,6 \%)$ \\
\hline Negative & $43(34,4 \%)$ \\
\hline \multicolumn{2}{|l|}{ Ki-67 status ${ }^{2)}$} \\
\hline low $\leq 15 \%$ & $63(50,4 \%)$ \\
\hline intermediate $16-30 \%$ & $41(32,8 \%)$ \\
\hline high $>30 \%$ & $20(16 \%)$ \\
\hline one value missing & $1(8 \%)$ \\
\hline \multicolumn{2}{|l|}{ Histologic type } \\
\hline Ductal & $110(88 \%)$ \\
\hline Lobular & $10(8 \%)$ \\
\hline Subtypes & $5(4 \%)$ \\
\hline \multicolumn{2}{|l|}{ Her2 $^{3)}$} \\
\hline IHC positive $(2+$ and $3+)$ & $25(20 \%)$ \\
\hline IHC negative ( 0 and $1+$ ) & $100(80 \%)$ \\
\hline \multicolumn{2}{|l|}{ CK $5 / 6^{4)}$} \\
\hline Triple-negative (ER-, PR-, Her2-) & $35(28 \%)$ \\
\hline $\begin{array}{l}\text { Basal-like carcinoma (ER-, PR-, Her2-, } \\
\text { CK5/6+) }\end{array}$ & $20(16 \%)$ \\
\hline \multicolumn{2}{|l|}{ Treatment after operation } \\
\hline Chemotherapy 27 & $(21,6 \%)$ \\
\hline Radiation 59 & $(47,2 \%)$ \\
\hline Hormonal therapy 24 & $(19,2 \%)$ \\
\hline
\end{tabular}

1,4) Cut off point used for ER and PR immunohistochemistry is $10 \%$ of positively stained tumour nuclei and $10 \%$ cytoplasmic staining for CK5/6.

2) Proliferation index according to St Gallen Consesus (Goldhirsch et al 2009).

3) Scoring of HER2 immunohistochemistry: Score 0: no staining is observed or cell membrane staining is observed in less than $10 \%$ of tumour cells. Score 1 +: a faint perceptible membrane staining can be detected in more than $10 \%$ of the tumour cells or cells are only stained in part of their membrane. Score $2+:$ a weak to moderate complete membrane staining is observed in more than $10 \%$ of the tumour cells. Score $3+$ : a strong complete membrane staining is observed in more than $10 \%$ of the tumour cells.

three separate cell rich areas were calculated with a $40 \times$ objective independently by two observers $(\mathrm{PB}, \mathrm{PH})$ without any knowledge of the clinical data and the mean value of immunopositive areas was recorded. In addition to tumour cells MMP-1 staining in non-lymphoid stromal cells was evaluated in the same way. The percentage of tumour cells with nuclear staining for hormonal receptors, Ki-67 and p53 was also recorded. For bcl-2, cytoplasmic staining was scored and the percentage of positive tumour cells was recorded. HER2 expression was evaluated as membrane staining of invasive tumour cells and scored to four classes $(0 / 1+/ 2+/ 3+)$. Triple-negative cases (ER-, PR- and HER2-) were stained with basal cytokeratin CK5/6, and expression was considered as positive, if at least $10 \%$ of the cancer cells showed cytoplasmic and/or membranous staining.

\section{Statistical analyses}

Statistical analyses were carried out using KruskalWallis and Mann-Whitney -tests. In pairwise comparison Bonferroni-adjustment was applied. Correlations were calculated using Spearman rank-order correlation coefficients. Non-parametric test was applied because of non-normal distribution of responses.

Breast cancer-specific survival time was determined from time of diagnosis until death from breast cancer. Patients who were alive at the end of the follow-up on October 2009 or died of other causes were used as censored values in survival analyses. Kaplan-Meier survival analyses were carried out to compare breast cancer-specific survival curves. Univariate Cox regression model was used to examine prognostic factors for breast cancer-specific survival. Factors significantly associated with disease-specific survival in univariate models were included in multivariate stepwise (inclusion and exclusion criteria $\mathrm{p}=0.05$ ) Cox regression model. Results are expressed using hazard ratios (HR) with 95\% confidence intervals (CI) and P-values less than 0.05 were considered as significant. The statistical analyses were carried out using SAS/STAT(r) software, Version 9.1.3 SP4 of the SAS System for Windows.

Cox univariate method was used to calculate breast cancer-specific survival analysis for 118 patients. The seven patients from this century were not included in survival data, because their treatment might have been different from earlier decades and because of the short follow-up. To examine interactions of different prognostic factors in a multivariate analysis, we used the Cox regression model. Parameters that achieved statistical significance for disease-specific survival in the log-rank test were included in the multivariate analysis.

\section{Results}

Immunohistochemical staining and statistical analyses

MMP-1 positivity in tumour cells and in stromal cells was observed in all analyzed tumours. The MMP-1 expression in tumour cells ranged from $10 \%$ to $95 \%$ and in stromal cells from $5 \%$ to $80 \%$. In tumour cells the MMP-1 expression was positive in $7.2 \%$ with value $\leq$ $30 \%$, in $8 \%$ with value $\leq 50 \%$, in $31.2 \%$ with value $\leq 70 \%$ and in $53.6 \%$ with value over $70 \%$. The MMP-1 positivity was lower in stromal cells, where $47.6 \%$ of cases were 


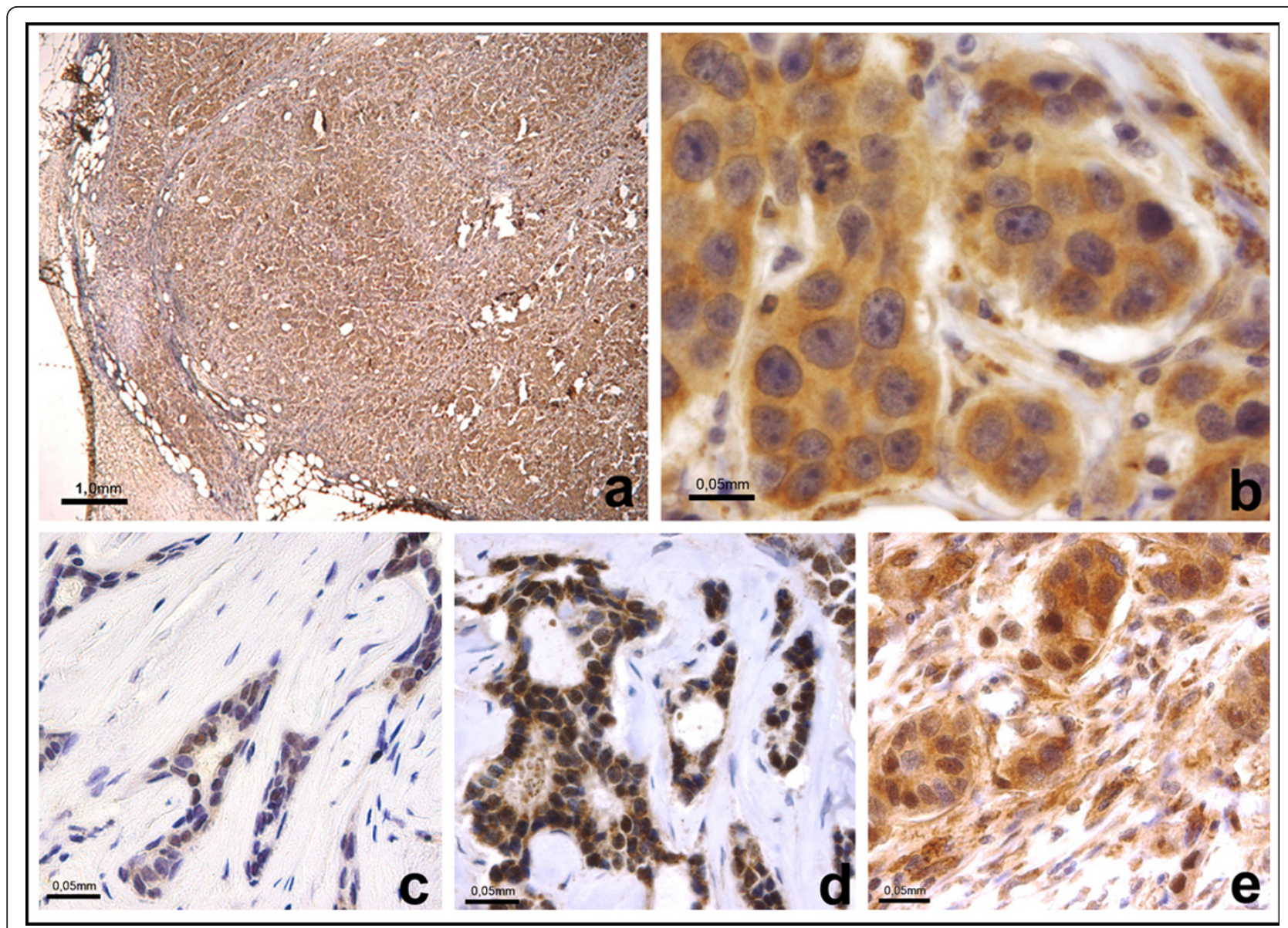

Figure 1 Immunohistochemical staining of MMP-1 in breast cancer. a-b) Immunohistochemical staining of MMP-1 in infiltrating ductal carcinoma GIII. The staining is observed both in nuclei and in the cytoplasm. c) Breast carcinoma cells with positive MMP-1 nuclear staining and with d) positive nuclear and cytoplasm staining and with e) positive tumour cells and cancer associated stromal cells.

positive with value $\leq 30 \%, 14.5 \%$ positive with value $\leq$ $50 \%, 30.6 \%$ positive with value $\leq 70 \%$ and $7.3 \%$ positive with value over $70 \%$. A positive correlation was seen between tumour grade and MMP-1 expression in tumour cells $(r=0.23, p=0.0101$, Figure 2$)$ and in stromal cells $(\mathrm{r}=0.21, \mathrm{p}=0.0170$, Figure 2$)$, the higher grade tumours showing stronger MMP-1 positivity.

The association between MMP-1 expression and traditional prognostic factors was evaluated. HER2 immunoreactivity correlated with MMP-1 positivity both in stromal cells $(\mathrm{r}=0.25, \mathrm{p}=0.0050)$ and tumour cells $(\mathrm{r}=0.22, \mathrm{p}=$ 0.0121). Using a dicotomised HER2 grouping into immunonegative $(0-1+$ classes $)$ and immunopositive $(2+-3+$ classes) groups, we also found a significant positive association between HER2 and MMP-1 expression in tumour cells $(p=0.0086)$ and in stromal cells $(p=0.0038)$. MMP1 positivity in cancer cells or in stromal cells did not show significant correlation with estrogen or progesterone receptors. P53 had a significant positive correlation with MMP-1 expression in tumour cells $(r=0.23, p=0.0113)$, but not in stromal cells. Ki-67 or Bcl-2 did not show any significant correlation with MMP-1 staining in tumour cells or in stromal cells.

We further evaluated the association between MMP-1 expression and the different molecular breast cancer subtypes. MMP-1 positivity in stromal cells showed significant differences $(p=0.0129)$ between breast cancer subtypes. In luminal B subtype, the MMP-1 expression in stromal cells was higher than in luminal A subtype ( $\mathrm{p}$ $=0.0258$ ), and also the luminal B subtype stromal cells showed higher MMP-1 positivity than triple-negative breast cancer cells $(\mathrm{p}=0.0336)$ (Figure 3$)$. MMP-1 expression in cancer cells did not show any association with these breast cancer subtypes. No association with MMP-1 positivity in tumour cells or in stromal cells was found when tumours were divided to triple-negative and non-triple-negative groups. Nor was any association found, when basal-like and non-basal-like groups and MMP-1 expression in tumour cells or in stromal cells were analyzed. 

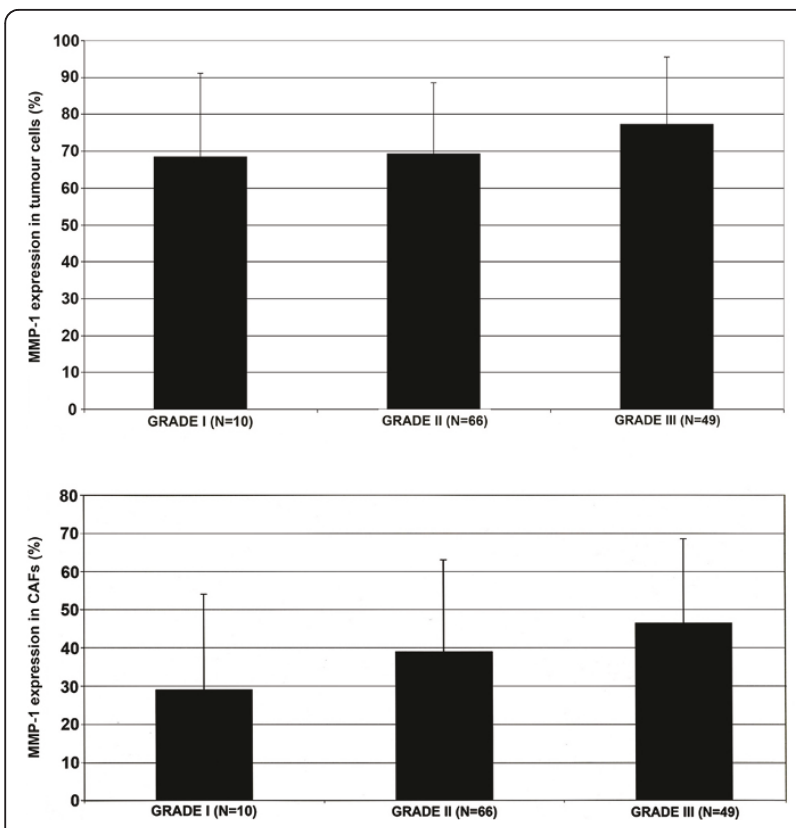

Figure 2 Correlation between tumour grade and MMP-1 immunoreactivity. The histograms present an association between the histological grade of the breast cancer and the immunohistochemical expression of MMP-1. P-values for MMP-1 expression in tumour cells: overall $p=0.023$, grade I vs. $\| p=1.0$, grade I vs. III $p=0.81$, grade II vs. III $p=0.0177$. P-values for MMP-1 expression in stromal cells: overall $p=0.0493$, grade I vs. $\| p=$ 0.4839 , grade I vs. III $p=0.1008$, grade II vs. III $p=0.2637$.

\section{Survival analysis}

The median follow-up period of the survived patients was 20 years (range, from 17 to 24 years). From the patients included in the survival analyses 44 patients $(37 \%)$ were still alive, 51 (43\%) had died from breast cancer and 23 (19\%) from some other cause during the follow up time.

There was a statistically significant difference in breast cancer-specific survival between tumours with high vs.

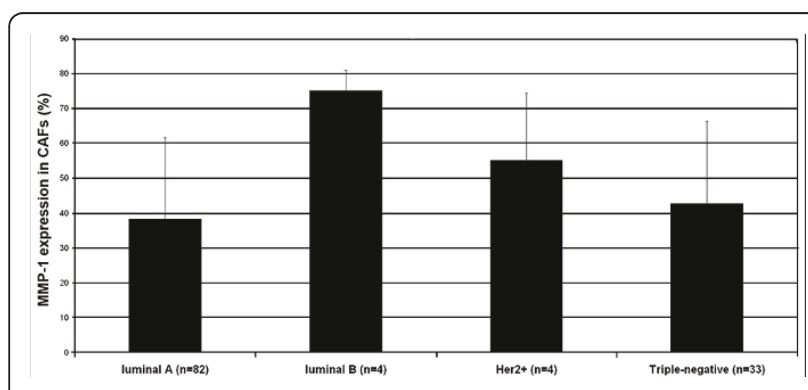

Figure 3 MMP-1 immunoreactivity of stromal cells of various breast cancer subtypes. Immunohistochemically detected expression of MMP-1 in stromal cells with significant differences in breast cancer subtypes. P-values for overall difference $p=0.0129$, luminal A vs. luminal B $p=0.0258$, luminal A vs. Her2 $p=0.8334$, luminal A vs. triple-negative $p=1.00$, luminal B vs. Her2 $p=0.3792$, luminal $B$ vs. triple-negative $p=0.0336$. low expression of MMP-1 in tumour cells (cut-off value $70 \%, \mathrm{p}=0.0171$ ) (Figure 4$)$, tumour grade I vs. III ( $\mathrm{p}=$ 0.0099), triple-negative vs. non-triple-negative breast cancers $(\mathrm{p}=0.0137)$, basal-like vs. non-basal-like breast cancers ( $\mathrm{p}=0.0103)$, low vs. high bcl-2 expression (cutoff value $25 \%, \mathrm{p}=0.0003$ ) and high vs. low estrogen receptor expression (cut-off value $10 \%, \mathrm{p}=0.0013$ ). The difference in breast cancer-specific survival between Ki-67 subcategories ( $\leq 15 \%$ and $>15 \%$ ) were also statistically significant $(\mathrm{p}=0.0022)$. There was no statistically significant difference in breast cancer-specific survival between MMP-1 positivity in stromal cells with any cutoff value (Figure 4). Neither did patient age or p53 expression associate with breast cancer-specific survival.

The potential independent prognostic value of MMP-1 protein expression in tumour cells was evaluated by stepwise Cox regression analysis. Ki-67 expression and high MMP-1 positivity in tumour cells (cut-off 70\%) were significantly associated with poor breast cancerspecific survival (Table 2). Positive bcl-2 status was a significant positive prognostic factor for breast cancerspecific survival (Table 2).

\section{Discussion}

Invasion of tumour cells is a multistep process that involves proteolytic activity and migration of tumours cells through the degraded ECM. The expression of MMP-1 is characteristic for many types of malignant tumours, including breast cancer. Upregulation of MMP1 was recently indicated to associate with poor outcome in breast cancer [20]. In this study, we evaluated MMP-1 expression by immunohistochemistry using original tissue sections instead of tissue microarrays, and correlated it with different breast cancer subtypes and with traditional prognostics factors and patient survival.

Our results demonstrate MMP-1 positivity both in the nuclei and in the cytoplasm of breast cancer cells and in the stromal cells, often termed as cancer-associated fibroblasts (CAFs). Our results showed a higher MMP-1 expression in tumour cells than in stromal cells. Earlier studies have demonstrated elevated nuclear MMP-1 expression in tumour cells [26], as well as in stromal fibroblasts $[15,23,27]$. Yet the results are conflicting and can be explained by the use of different tissue handling, fixation and incubation conditions as well as different antibodies used [28]. Also the scoring criteria for each antibody should be standardized. The antibody we used recognises both the latent and active forms of MMP-1 protein.

In our study, MMP-1 expression in tumour cells and in stromal cells showed a significant association with tumour grade. This finding is partially in line with previous data [29], where CAFs showed a correlation with tumour stage. Earlier studies have also shown elevation 


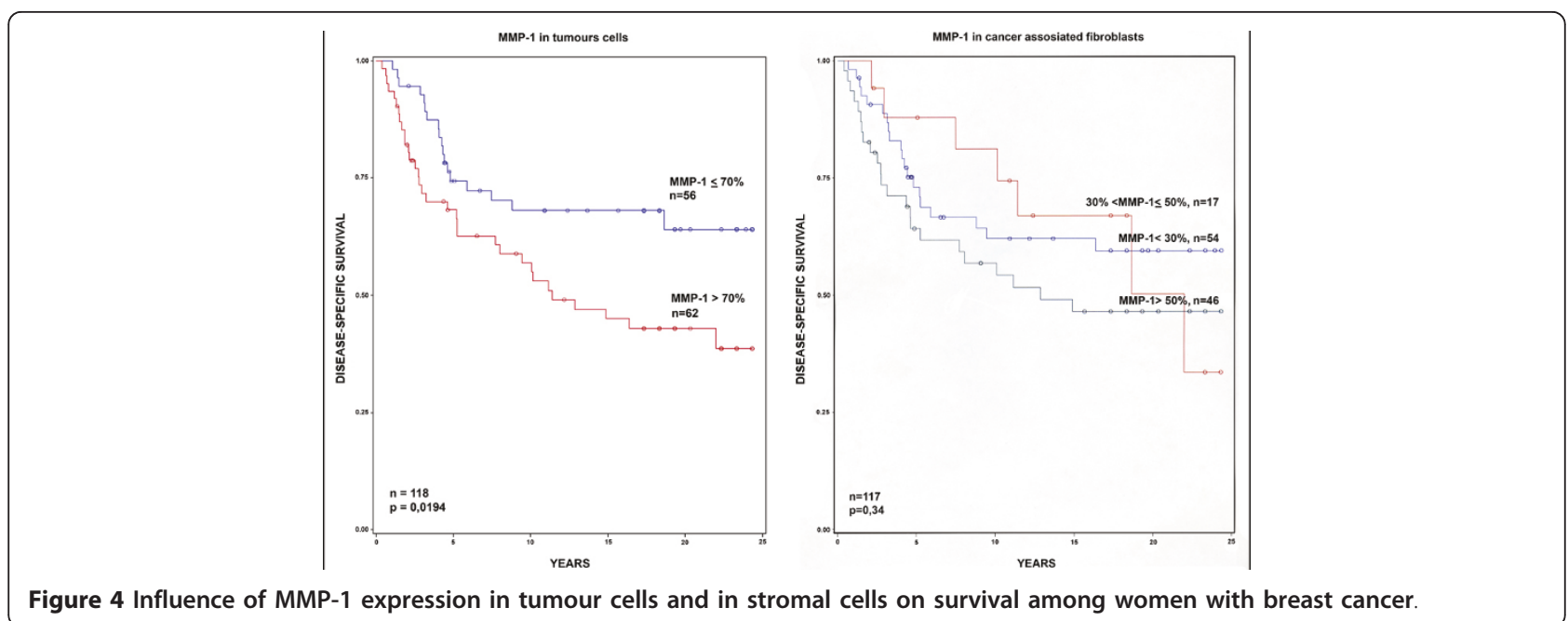

of MMP-1 mRNA in high-grade tumours when compared to low-grade tumours [20,30], but also opposite results on MMP-1 immunohistochemical expression and tumour grade exist [28].

In previous studies high expression on MMP-1 by stromal cells correlated with the occurrence of metastasis [23] suggesting that tumoural stromal tissue is important in cancer progression [31]. In our study, the expression of MMP-1 both in tumour cells and in stromal cells and especially the correlation between the expression and tumour grade may indicate an impact of MMP-1 on cellular properties such as growth, death, and migration [32]. MMPs are known to cleave not only structural components of the ECM, but also growth factor precursors, cell surface receptors, cytokines and cell adhesion molecules [18,33].

Hormone receptors are associated with a favourable prognosis and predict response to endocrine treatment [34]. In our analysis the MMP-1 positivity did not show any correlation with hormone receptors. However, we found a negative, but not a significant correlation between tumour cell MMP-1 expression and ER expression. MMP-1 expression has previously been reported to be significantly increased in ER-negative breast cancer $[20,35]$. In a previous study MMP-1 expression and PR expression had a statistically significant inverse correlation with CAFs and cancer cells [29]. Also the positive correlation between HER2 and MMP-1 expression both in tumour cells and stromal cells in our study shows that MMP-1 is associated with poor outcome in breast cancer. Our result showing the correlation between p53 and MMP-1 expression in tumour cells is in accordance with tumour aggressiveness.

One important finding of the present study is the significantly different MMP-1 expression in stromal cells of different breast cancer subtypes (Figure 3). In our study MMP-1 overexpression in tumour cells did not have any significant differences within breast cancer subtypes. On the other hand, we did not find any association between luminal or basal-like breast tumours and MMP-1 positivity in tumour cells. Similar results have been presented by González [36]. However, MMP-1 mRNA is shown to

Table 2 Disease specific- survival analysis at 24 years follow-up

\begin{tabular}{|c|c|c|c|c|c|}
\hline Variable & $\mathrm{n}$ & $\mathrm{HR}(95 \% \mathrm{Cl})$ & p (univariate) & $\mathrm{HR}(95 \% \mathrm{Cl})$ & p (multivariate) \\
\hline ER $>10 \%$ & 118 & $0.41(0.24-0.72)$ & $0.0018^{*}$ & & \\
\hline$P R>10 \%$ & 118 & $0.71(0.40-1.25)$ & 0.2322 & & \\
\hline Ki-67 > 15\% & 117 & $2.35(1.34-4.13)$ & $0.0030^{*}$ & $2.01(1.12-3.59)$ & $0.0186^{*}$ \\
\hline $\mathrm{Bcl}-2>25 \%$ & 118 & $0.33(0.18-0.63)$ & $0.0007^{*}$ & $0.45(0.23-0.86)$ & $0.0158^{*}$ \\
\hline Triple-neg & 118 & $2.05(1.15-3.68)$ & $0.0158^{*}$ & & \\
\hline Basal-type & 118 & $2.34(1.20-4.58)$ & $0.0127^{*}$ & & \\
\hline p53 > 10\% & 118 & $1.73(0.98-3.06)$ & 0.0601 & & \\
\hline MMP-1 tumour cells > 70\% & 118 & $1.99(1.12-3.53)$ & $0.0194^{*}$ & $1.81(1.01-3.22)$ & $0.0438^{*}$ \\
\hline MMP-1 fibroblasts > $30 \%$ & 118 & $1.35(0.77-2.39)$ & 0.2948 & & \\
\hline
\end{tabular}

$\mathrm{HR}=$ Hazard Ratio

P-value less than $0.05\left(^{*}\right)$ were considered as significant.

Tumour grade was not included in disease specific -survival analysis, because none of grade I patients died of breast cancer. 
be up-regulated in basal-type breast cancers when compared with non-basal-type breast cancers [20].

Few studies have correlated MMP-1 expression with breast cancer-specific survival. In our study the follow up -time for breast cancer-specific survival was extensively long being over 20 years. We found that MMP-1 positivity in tumour cells with a $70 \%$ cut-off level had a significant association with survival in univariate analyses (Figure 4). The breast cancer-specific survival curve continued to decrease even during the extended follow-up period. In addition, tumour grade, triple-negative and basal-like breast cancers, ER, Ki-67 and bcl-2, were associated with breast cancer-specific survival in our study. In a multivariate analysis the presence of MMP-1 positivity in tumour cells had an independent prognostic value as did Ki-67 and bcl-2 immunoreactivity. No statistically significant difference was found in breast cancer-specific survival in the expression of MMP-1 in stromal cells with any cut-off values (Figure 4).

\section{Conclusions}

In summary, our study shows that both tumoural and stromal MMP-1 positivity is associated with breast tumour progression and poor prognosis. Our findings show a significant difference in MMP-1 positivity of cancer associated stromal cells between luminal A, luminal B and triple-negative breast cancer types. The most important finding of the present work is that the MMP-1 expression of tumour cells carries an independent prognostic value in breast cancers. These results suggest that MMP-1 expression of both stromal and tumour cells may control breast cancer progression. Further investigation with larger patient cohorts is needed to better understand the function of MMP-1 in tumour cells.

\section{List of abbreviations}

CAF: cancer associated fibroblast; DC: ductal carcinoma; LC: Iobular carcinoma; ECM: extracellular matrix; ER: estrogen receptor; HER2: human epidermal growth factor receptor 2; PR: progesterone receptor; CK5/6: cytokeratin 5/6; MMPs: matrix metalloproteinases; TIMPs: tissue inhibitors of matrix metalloproteinases

\section{Acknowledgements and Funding}

The expert technical assistance of Sinikka Kollanus is gratefully acknowledged. The authors thank also Jaakko Liippo for helping with photographing. This study was financially supported by the Turku University Hospital, Cancer Foundation of South-Western Finland and by grant from the Finnish Breast Cancer Group.

\section{Author details}

'University of Turku and Turku University Central Hospital, Department of Pathology, Kiinamyllynkatu 10, 20520 Turku, Finland. ${ }^{2}$ University of Turku, Department of Biostatistics, Lemminkäisenkatu 1, 20014 Turku, Finland. ${ }^{3}$ Turku University Central Hospital, Department of Surgery, Kiinamyllynkatu 4 - 8, 20520 Turku, Finland.

\section{Authors' contributions}

PB participated in the design of the study, carried out the screening of the tumour material and the evaluation of the immunohistochemical staining and drafted the manuscript. MS participated in the study design and helped to draft the manuscript. TV coordinated and performed the statistical analysis and helped to draft the manuscript. KOS and PJR participated in the design of the study. PJR and OC helped to draft the manuscript. PH participated in the design of the study, carried out the evaluation and validation of the immunohistochemical staining and helped to draft the manuscript. All authors have read and approved the final manuscript.

\section{Competing interests}

The authors declare that they have no competing interests.

Received: 31 January 2011 Accepted: 11 August 2011

Published: 11 August 2011

\section{References}

1. WHO: Women's health. 2009, Fact sheet No 334.

2. Malamou-Mitsi V, Gogas H, Dafni U, Bourli A, Fillipides T, Sotiropoulou M, Vlachodimitropoulos D, Papadopoulos S, Tzaida O, Kafiri G, Kyriakou V Markaki S, Papaspyrou I, Karagianni E, Pavlakis K, Toliou T, Scopa CD, Papakostas P, Bafaloukos D, Christodoulou C, Fountzilas G: Evaluation of the prognostic and predictive value of p53 and $\mathrm{Bcl}-2$ in breast cancer patients participating in a randomized study with dose-dense sequential adjuvant chemotherapy. Ann Oncol 2006, 17:1504-1511.

3. Joensuu H, Pylkkänen L, Toikkanen S: Bcl-2 Protein Expression and LongTerm Survival in Breast Cancer. Am J Pathol 1994, 145:1191-1198.

4. Martinez-Arribas F, Alvarez T, Del Val G, Martin-Garabato E, Nunez-Villar MJ, Lucas R, Sanchez J, Tejerina A, Schneider J: Bcl-2 expression in breast cancer: a comparative study at the mRNA and protein level. Anticancer Res 2007, 27:219-222.

5. Ellis P, Schnitt S, Sastre-Garau X, Bussolati G, Tavassoli F, Eusebi V, Peterse J, Mukai K, Tabar L, Jacquemier J, Cornelisse C, Sasco A, Kaaks R, Pisani P, Goldgar D, Devilee P, Cleton-Jansen M, Borresen-Dale A, van't Veer L, Sapino A: WHO Classification of Tumours. Pathology and Genetics of Tumours of the Breast and Female Genital Organs.Edited by: Tavassoli FA \& Devilee P. Lyon; 2003:9-59.

6. Perou C, Sørlie T, Elsen M, van de Rijn M, Jeffrey S, Rees C, Pollack J, Ross D, Johnsen $H$, Akslen L, Fluge $\varnothing$, Pergamenschlkov A, Williams C, Zhu S, Lønning P, Børresen-Dale A-L, Brown P, Botstein D: Molecular portraits of human breast tumours. Nature 2000, 406:747-752.

7. Sørlie T, Perou C, Tibshirani R, Aas T, Geisler S, Johnsen H, Hastie T, Eisen M, van de Rijn M, Jeffrey S, Thorsen T, Quist H, Matese J, Brown P, Botstein D, Lønning P, Børresen-Dale A-L: Gene expression patterns of breast carcinomas distuinguish tumor subclasses with clinical implications. Proc Natl Acad Sci 2001, 98:10869-10874

8. Foulkes W, Smith I, Reis-Filho J: Triple-Negative Breast Cancer. N Engl J Med 2010, 363:1938-1948.

9. Hanahan D, Weinberg RA: The hallmarks of cancer. Cell 2000, 100:57-70.

10. García M, González-Reyes S, González L, Junquera S, Berdize N, Del Casar J, Medina M, Vizoso F: Comparative study of the expression of metalloproteases and their inhibitors in different localizations within primary tumours and in metastatic lymph nodes of breast cancer. Int J Exp Path 2010, 91:324-334.

11. Nagase $H$, Visse $R$, Murphy $G$ : Structure and function of matrix metalloproteinases and TIMPs. Cardiovascular Research 2006, 69:562-573.

12. Hesek D, Toth M, Meroueh S, Brown S, Zhao H, Sakr W, Fridman R, Mobashery S: Design and Characterization of a Metalloproteinase Inhibitor-Tethered Resin for the Detection of Active MMPs in Biological Samples. Chemistry \& Biology 2006, 13:379-386.

13. Deryugina E, Quigley J: Matrix metalloproteinases and tumor metastasis. Cancer Metastasis Rev 2006, 25:9-34.

14. Del Casar J, González-Reyes S, González L, González J, Junquera S, Bongera M, García M, Andicoechea A, Serra C, Vizoso F: Expression of metalloproteases and their inhibitors in different histological types of breast cancer. J Cancer Res Clin Oncol 2010, 136:811-819.

15. Roy R, Yang J, Moses M: Matrix Metalloproteinases As Novel Biomarkers and Potential Therapeutic Targets in Human Cancer. J Clin Oncol 2009, 27:5287-5297.

16. Zhou P, Du LF, Lv GQ, Yu XM, Gu YL, Li JP, Zhang C: Current evidence on the relationship between four polymorphisms in the matrix metalloproteinases (MMP) gene and breast cancer risk: a meta-analysis. Breast Cancer Res Treat 2011, 127:813-818. 
17. Vihinen $P$, Kähäri V-M: Matrix metalloproteinases in cancer: prognostic markers and therapeutic targets. Int J Cancer 2002, 99:157-166.

18. Egeblad M, Werb Z: New functions for the matrix metalloproteinases in cancer progression. Nat Rev Cancer 2002, 2:161-174

19. Brinckerhoff C, Rutter J, Benbow U: Interstitial Collagenases as Markers of Tumor Progression. Clin Cancer Res 2000, 6:4823-4830

20. McGowan PM, Duffy MJ: Matrix metalloproteinase expression and outcome in patients with breast cancer: analysis of a published database. Ann Oncol 2008, 19:1566-1572.

21. Minn A, Gupta G, Siegel P, Bos P, Shu W, Giri D, Viale A, Olshen A Gerald W, Massague J: Genes that mediate breast cancer metastasis to lung. Nature 2005, 436:518-524

22. Eck S, Hoopes P, Petrella B, Coon C, Brinckerhoff C: Matrix metalloproteinase-1 promotes breast cancer angiogenesis and osteolysis in a novel in vivo model. Breast Cancer Res Treat 2009, 116:79-90.

23. Vizoso FJ, Gonzáles LO, Corte MD, Rodriguez JC, Vazquez J, Lamelas ML, Junquera S, Merino AM, Garcia-Muniz JL: Study of matrix metalloproteinases and their inhibitors in breast cancer. Br J Cancer 2007 96:903-911.

24. Elston CW, Ellis IO: Pathological prognostic factors in breast cancer. I. The value of histological grade in breast cancer: experience from a large study with long-term follow up. Histopathology 1991, 19:403-410.

25. Boström P, Söderström M, Palokangas T, Vahlberg T, Collan Y, Carpen O, Hirsimäki P: Analysis of cyclins A, B1, D1 and E in breast cancer in relation to tumour grade and other prognostic factors. BMC Res Notes 2009, 2:140

26. Köhrmann A, Kammerer U, Kapp M, Dietl J, Anacker J: Expression of matrix metalloproteinases (MMPs) in primary human breast cancer and breast cancer cell lines: New findings and review of the literature. BMC Cancer 2009, 9:188.

27. Heppner K, Matrisian L, Jensen R, Rodgers W: Expression of Most Matrix Metalloproteinase Family Members in Breast Cancer Represents a Tumor-Induced Host Response. Am J Pathol 1996, 149:273-282.

28. Baker $E$, Stephenson $T$, Reed M, Brown N: Expression of proteinases and inhibitors in human breast cancer progression and survival. J Clin Pathol: Mol Pathol 2002, 55:300-304.

29. Nakopoulou L, Giannopoulou I, Gakiopoulou H, Liapis H, Tzonou A, Davaris P: Matrix metalloproteinase- 1 and -3 in breast cancer: correlation with progesterone receptors and other clinicopathologic features. Hum Pathol 1999, 30:436-442.

30. Duffy M, Maguire T, Hill A, McDermott E, O'Higgins N: Metalloproteinases: role in breast carcinogenesis, invasion and metastasis. Breast Cancer Res 2000, 2:252-257.

31. Przybylowska K, Kluczna A, Zadrozny M, Krawczyk T, Kulig A, Rykala J, Kolacinska A, Morawiec Z, Drzewoski J, Blasiak J: Polymorphismus of the promoter regions of matrix metalloproteinases genes MMP-1 and MMP9 in breast cancer. Breast Cacer Res Treat 2006, 95:65-72.

32. Coussens L, Fingleton B, Matrisian L: Matrix Metalloproteinase Inhibitors and Cancer: Trials and Tribulations. Science 2002, 295:2387-2392.

33. González L, Corte M, Vázquez J, Junquera S, Sanchez R, Alvarez A Rodriguez J, Lamelas M, Vizoso F: Androgen receptor expression in breast cancer: Relationship with clinicopathological characteristics of the tumors, prognosis, and expression of metalloproteases and their inhibitors. BMC Cancer 2008, 8:149.

34. Soerjomataram I, Louwman M, Ribot J, Roukema J, Coebergh J: An overview of prognostic factors for long-term survivors of breast cancer. Breast Cancer Res Treat 2008, 107:309-330.

35. Cheng S, Tada M, Hida Y, Asano T, Kuramae T, Takemoto N, Hamada J-I, Miyamoto M, Hirano S, Kondo S, Moriuchi T: High MMP-1 mRNA Expression is a Risk Factor for Disease-Free and Overall Survivals in Patients with Invasive Breast Carcinoma. J Surgical Res 2008, 146:104-109.

36. González L, Corte M, Junquera S, González-Fernández R, del Casar J, García C, Andicoechea A, Vázquez J, Pérez-Fernández R, Vizoso F: Expression and prognostic significance of metalloproteases and their inhibitors in luminal $\mathrm{A}$ and basal-like phenotypes of breast carcinoma. Human Pathol 2009, 40:1224-1233.

Pre-publication history

The pre-publication history for this paper can be accessed here:

http://www.biomedcentral.com/1471-2407/11/348/prepub doi:10.1186/1471-2407-11-348

Cite this article as: Boström et al:: MMP-1 expression has an

independent prognostic value in breast cancer. BMC Cancer 2011 11:348.

\section{Submit your next manuscript to BioMed Central and take full advantage of:}

- Convenient online submission

- Thorough peer review

- No space constraints or color figure charges

- Immediate publication on acceptance

- Inclusion in PubMed, CAS, Scopus and Google Scholar

- Research which is freely available for redistribution

Submit your manuscript at www.biomedcentral.com/submit
C) Biomed Central 